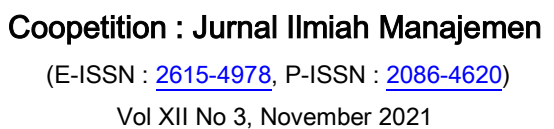

\title{
Analisis Unsur Yang Mempengaruhi Hubungan Antara Pekerja dan Pengusaha
}

\author{
M Dana Prihadi \\ Akademi Perekam Medis Dan Informatika Kesehatan Bandung \\ danaprihadi@apikesbandung.ac.id
}

\begin{abstract}
ABSTRAK
Penelitian ini dilakukan untuk menguji pengaruh pandangan pekerja tentang peraturan perundangan di lingkungan kerja, keberadaan serikat pekerja dan hubungan antara pekerja dengan pengusaha. Peneliti malakukan beberapa tahap, pertama yang dilakukan adalah untuk mengukur pengaruh pemahaman tentang regulasi di bidang ketenagakerjaan, kedua untuk mengukur pengaruh pandangan pekerja tentang kesejahteraan kerja, ketiga untuk mengukur pengaruh pandangan pekerja tentang keberadaan serikat pekerja, dan keempat adalah hubungan antara pekerja dan pengusaha dengan menggunakan nilai alpha cronbach sebesar 0,6. Pada penelitian ini digunakan alat uji analisis regresi linier berganda serta uji asumsi klasik. Hasil dari penelitian ini adalah menunjukkan adanya pengaruh positif dan signifikan diantara pengaruh pandangan pekerja tentang peraturan undangan di bidang perburuhan. Kemakmuran tenaga kerja dan harmonisasi hubungan antara pekerja dan pengusaha secara simultan.
\end{abstract}

Kata Kunci: pekerja, serikat pekerja, kesejahteraan, hubungan kerja

\begin{abstract}
This research was conducted to determine workers' perceptions about the laws and regulations in the work environment, the existence of trade unions and the harmonization of relations between workers and employers. The researcher carried out several stages, the first that was carried out was to measure the influence of understanding of regulations in the field of manpower, second to measure workers 'perceptions of work welfare, third to measure the effect of workers' perceptions on the existence of workers, and fourth to measure the harmonization between workers and employers using alpha values cronbach of 0.6. The research used multiple linear regression analysis tools and classical assumption test. The results of this study indicate a positive and significant influence among workers' perceptions of the invitational regulations in the labor sector. Prosperity of the workforce and harmonization of relations between workers and employers simultaneously.
\end{abstract}

Keywords: workers, labor unions, welfare, work relations

\section{PENDAHULUAN}

Kemajuan dunia industrialisasi semakin pesat dan bedampak langsung pada peningkatan lapangan kerja. Jumlah tenaga kerja yang dibutuhkan juga akan mengalami peningkatan. Hal ini berdampak pada potensi timbulnya masalah dalam hubungan industrial, hubungan kerja, bahkan masalah ini dapat menimbulkan kerawanan.

Faktor-faktor yeng menyababkan kerawanan tersebut bisa saja berasal dari pemilik perusahaan, pekerja, aparat pemerintah maupun perundang-undangan yang dinilai tidak sesuai lagi dengan perkembangan saat ini. Selain itu perkembangan dunia internasional turut menjadi bagian penguatan pada masalah tersebut. Hal ini membawa perubahan hubungan antara pimpinan perusahaan dengan pekerja yang dinilai dalam posisi lemah.
Guna mengatasi masalah tersebut, perlu adanya upaya atau langkah kongkrit dari pihak pengusaha. Upaya penting yang perlu dilakukan antara lain adalah sosialisasi peraturan perundang-undangan, implementasi peraturan perundang-undangan, pembinaan, menjalin komunikasi dan memberikan perhatian kepada para pekerja yang berkaitan dengan peningkatan kesejahteraan. Perlu dilakukan peningkatan pengetahuan pekerja perihal peraturan perundang-undangan khususnya di bidang ketenagakerjaan termasuk tahapan tata cara penyelesaian masalah hubungan industrial dan masalah ekonomi perusahaan.

Adanya perasaan para pekerja bahwa kesejahteraan mereka kurang diperhatikan, yang mana sebenarnya pekerja tidak hanya merupakan alat dalam produksi melainkan juga sebagai aset penting dan mitra kerja pengusaha guna mempertahankan serta meningkatkan 
perusahaan. Selain adanya ketidakharmonisan hubungan kemitraan diantara pengusaha dengan para pekerja yang disebabkan oleh masalah kesejahteraan pekerja, masalah keberadaan serikat pekerja di perusahaan dan kurang terbukannya sistem manajemen perusahaan juga menjadi penyebab timbulnya konflik dalam perusahaan. Permasalahan yang muncul bermacam-macam dan tidak hanya secara teknis pada hubungan industrial, tetapi berbagai masalah lain yang semakin komplek dan berkembang serta berdampak pada stabilitas sosial. Untuk mencegah timbulnya perselisihan hubungan industrial, pengusaha dapat mengambil berbagai langkah strategis. Untuk itu memang diperlukan perhatian khusus dari pengusaha berkaitan dengan hak-hak pekerja/buruh, pemeliharaan hubungan baik dengan pekerja/buruh dan hubungan industrial secara umum. Tidak sedikit aksi demo dan mogok kerja terjadi karena masalah yang tidak tertangani.

\section{KAJIAN PUSTAKA}

\section{Pandangan}

Pandangan merupakan suatu proses kognitif yang membantu individu dalam memilih, mengatur, menyimpan dan menginterpretasikan rangsangan menjadi gambaran dunia yang utuh dan berarti. (Gibson,Ivan Cevich dan Donelly 1996).

Menurut Moskowitz dan Orgel (1969) (Walgito, 1990) pandangan adalah proses mengorganisasikan, mengingterprestasikan rangsangan yang diterima individu kemudian diolah, merupakan sesuatu yang memiliki makna dan menjadi satukesatuan dalam diri individu. Sedangkan menurut (Robbins, 1996), pandangan merupakan sebuah proses yang dilakukan dan dilalui individu dalam mengorganisasikan dan mengartikan kesan-kesan indera mereka sehingga dapat memberikan arti dan informasi bagi mereka.

Faktor yang Mempengaruhi Pandangan antara lain pertama, pelaku pandangan (Perceiver) maksudnya Jika seorang individu melihat terfokus pada sebuah objek dan melakukan penafsiran tentang apa yang dilihatnya, penafsiran tersebut sangat kuat dipengaruhi oleh pribadi, dan karakteristik individu itu. Kedua target yang dipandang, jadi karakteristik, jenis, dan penafsiran dari target yang akan diamati bisa saja memberikan pengaruh tentang apa yang dipandang. Target yang dipandang dalam keadaan bebas dan latar belakang dari target akan mempengaruhi pandangan terhadap terget tersebut. Ketiga situasi saat melakukan pandangan. Unsur-unsur lingkungan disekitar individu akan memberikan pengaruh pada proses pandangan. Waktu, lokasi, cahaya, merupakan hal di mana suatu objek/kejadian itu dapat mempengaruhi perhatian dan cara pandang individu.

Pemahaman Peraturan Perundangan di Bidang Ketenagakerjaan sangatlah penting. Peraturan perundangan di bidang ketenagakerjaan bidang hubungan industrial, syarat-syarat kerja dan Penempatan Tenaga Kerja Asing (PTKA) merupakan norma-norma yang harus diindahkan dan dipahami bersama oleh semua pihak yang terkait dengan masalah ketenagakerjaan, baik oleh pekerja/buruh, pengusaha maupun oleh aparat pemerintah sendiri.

Selain daripada itu, ada istilah Pemutusan Hubungan Kerja (PHK) yang merupakan mengakhiri hubungan kerja dikarenakan suatu hal dan lainnya yang berakibat berakhirnya hak serta kewajiban antara pekerja/buruh dengan pengusaha. (UU No.13 Tahun 2003). Pengertian Pemutusan Hubungan Kerja (PHK) adalah apabila ikatan formal diantara organisasi ataupun perusahaan sebagai pengguna jasa tenaga kerja dan buruh terputus. (Sondang P.Siagian, 2002).

Faktor-faktor sebagai penyebab timbulnya pemutusan hubungan kerja adalah tenaga kerja mengundurkan diri berdasarkan kemauannya sendiri, tenaga kerja meninggal dunia, telah berakhir perjanjian kerja pada waktu tertentu, alasan lain yang memaksa perusahaan, Force Majeur (Bencana alam, kebakaran, dll), serta karena usia pensiun tenaga kerja. Perusahaan tidak diperbolehkan mengambil keputusan tentang pemutusan hubungan kerja dengan alasan bahwa pekerja tidak hadir kerja dikarenakan sakit selama tidak lewat 12 bulan terus menerus; pekerja menunaikan tugas dan kewajiban terhadap negara sebagaimana perundangan yang berlaku; pekerja beribadah; pekerja menikah; pekerja sedang hamil, melahirkan, keguguran saat hamil, dan menyusui bayinya; pekerja memiliki hubungan darah dan atau ikatan perkawinan terhadap pekerja lain dalam satu perusahaan kecuali diatur lain dalam perjanjian kerja/ peraturan perusahaan/perjanjian kerja bersama, pekerja mendirikan dan menjadi anggota pengurus serikat pekerja dan melakukan kegiatan serikat pekerja pada jam kerja atau luar jam kerja, mengadukan pengusaha kepada yang berwajib, pekerja memiliki perbedaan pandangan, agama, aliran politik, suku, golongan, jenis kelamin, kondisi fisik, atau status perkawinan, pekerja dalam keadaan cacat tetap, sakit akibat kecelakaan kerja, atau sakit karena hubungan kerja yang menurut keterangan dokter penyembuhannya tidak dapat dipastikan.

\section{Kesejahteraan Pekerja/Buruh}

Kesejahteraan adalah suatu pemenuhan kebutuhan dan/atau keperluan yang bersifat jasmania dan rohania, baik didalam maupun diluar hubungan kerja, yang secara langsung atau tidak langsung dapat mempertinggi produktivitas kerja dalam lingkungan kerja yang aman dan sehat,

\section{- Maksud}

Untuk meningkatkan pendapatan pekerja sebagai pelaksana pembangunan nasional dan terwujudnya 
kegiatan yang menguntungkan bagi pertumbuhan dan perkembangan pekerja yang meliputi aspek psykologis, sosial budaya, ekonomi, politik serta yuridis.

\section{- Tujuan}

Menjamin kebutuhan dasar pekerja secara wajar yang menyangkut segi-segi kelangsungan hidup, pertumbuhan dan perkembangan serta perlindungan pekerja yang menjuadi haknya, agar menjadi manusia Indonesia seutuhnya serta membina lingkungan hidup pekerja yang menguntungkan bagi kesejahteraan pekerja dan keluarganya.

- Manfaat

Kesejahteraan pekerja yang meningkat di samping dapat meningkatkan ketenangan kerja dan ketenangan berusaha sekaligus akan dapat meningkatkan ketahanan nasional dan stabilitas nasional yang pada gilirannya akan membuka jalan bagi kemajuan usaha untuk mencapai masyarakat pekerja yang produktif.

\section{Unsur-unsur Kesejahteraan Pekerja}

\section{- Pendapatan (Take home pay)}

Pengertian pendapatan adalah hasil yang diterima pekerja sebagai imbalan atas prestasi yang diberikan oleh pengusaha/perusahaan. Pendapatan pekerja dapat berupa : upah pokok, tunjangan tetap dan tunjangan tidak tetap, pendapatan non upah

\section{- Jaminan Sosial Tenaga Kerja (Jamsostek)}

Adalah suatu perlindungan bagi tenaga kerja dalam bentuk santunan berupa uang sebagai pengganti sebagian dari penghasilan yang hilang atau berkurang dan pelayanan sebagai akibat peristiwa atau keadaan yang dialami oleh tenaga kerja berupa kecelakaan kerja, sakit, hamil, bersalin, hari tua dan meninggal dunia. (UU No.3 Tahun 1992). Program Jaminan Sosial Tenaga Kerja meliputi:
a) Jaminan Kecelakaan Kerja (JKK)
b) Jaminan Kematian (JK)
c) Jaminan Hari Tua (JHT)
d)Jaminan Pemeliharaan Kesehatan (JPK)
- Fasilitas Kesejahteraan pekerja.

Yang dimaksud dengan fasilitas kesejahteraan pekerja antara lain berupa pelayanan Keluarga Berencana (KB), Tempat penitipan anak (TPA), Perumahan pekerja/buruh, fasilitas ibadah, olahraga, kantin, fasilitas kesehatan dan fasilitas rekreasi.

\section{- Rasa Aman (Sense of security)}

Yang dimaksud adalah adanya kepastian atas kelangsungan pekerjaan dan penghasilan yang diperoleh pekerja/buruh hingga hari tuanya. Dalam hal ini termasuk jaminan dan kepastian bahwa pekerja dan keluarganya akan mendapat pelayanan kesehatan dan tunjangan, khususnya pada saat sangat diperlukan.

\section{- Harmonisasi Hubungan Kemitraan.}

Harmonis adalah suatu kondisi atau keadaan di mana antara pekerja dan pengusaha tercipta hubungan yang serasi, selaras dan seimbang. (Moedjianto, 1997)

\section{Hubungan Kemitraan :}

Adalah Suatu hubungan yang terjalin erat dan harmonis di antara para pelaku proses produksi barang dan jasa di perusahaan (Pekerja dan Pengusaha) yang dilandasi oleh prinsip Hubungan Industrial Pancasila (HIP). Sebuah kemitraan yang dikaitkan pada Hubungan Industrial Pancasila (HIP) dapat berupa halhal sebagai berikut :

\section{- Kemitraan pada proses produksi.}

Menyatakan pekerja, pengusaha serta pemerintah memiliki andil dan berpartisipasi dalam mewujudkan proses produksi sesuai fungsinya masing-masing.

- Kemitraan dalam keuntungan.

Pekerja, pengusaha serta pemerintah bisa mendapatkan kegunaan dan faedah dari sebuah keuntungan yang diperoleh perusahaan dalam ukuran proporsional.

- Kemitraan dalam tanggung jawab.

Pekerja, pengusaha serta pemerintah wajib bertanggung jawab pada kemajuan, perkembangan dan keberlangsungan bisnis dikarenakan perusahaan merupakan aset nasional dan harus dijaga oleh seluruh pihak.

\section{Hipotesis}

H1:Pandangan pekerja tentang pemahaman peraturan perundangan dibidang ketenagakerjaan berpengaruh positip dan signifikan terhadap harmonisasi hubungan kemitraan antara pekerja dan pengusaha.

$\mathrm{H} 2$ :Pandangan pekerja tentang kesejahteraan pekerja berpengaruh positip dan signifikan terhadap harmonisasi hubungan kemitraan antara pekerja dan pengusaha.

H3:Pandangan pekerja tentang keberadaan serikat pekerja/serikat buruh berpengaruh positif dan signifikan terhadap harmonisasi hubungan kemitraan antara pekerja dan pengusaha.secara simultan.

\section{METODE PENELITIAN}

Populasi pada penelitian ini adalah para pekerja yang masuk sebagai serikat pekerja di perusahaan wilayah Kabupaten Bandung Barat. Teknik pengambilan sampel dilakukan dengan metode pengambilan sampel non probabilitas (pemilihan non random) khususnya dengan metode Convenience Sampling, yaitu 
dilakukan dengan memilih sampel bebas sesuai kebutuhan peneliti. Dalam hal ini populasi terdapat lebih dari 100 perusahaan yang memiliki serikat pekerja/serikat buruh, sedangkan besarnya sampel yang diambil 100 perusahaan. Pandangan pekerja pada pemahaman peraturan perundangan ketenagakerjaan, kesejahteraan, dan serikat pekerja merupakan variable bebas, hubungan yang harmonis antara pekerja dan pengusaha yang menjadi variable terikat.

Jenis data yang digunakan adalah data kuantitatif hasil angket kuesioner tentang pemahaman peraturan perundangan ketenagakerjaan, kesejahteraan, dan serikat pekerja. Skala yang digunakan dalam penyusunan keusioner adalah skala likert dengan lima tingkat jawaban. Uji validitas menggunakan Pearson's correlation, sedangkan Cronbach Alpha digunakan unutk uji reliabilitas dan memakai SPSS for Windows versi 12 .

\section{HASIL DAN PEMBAHASAN}

Untuk kepengurusan serikat pekerja di perusahaan pada umumnya berkisar antara 5 orang sampai dengan 12 orang personil. Uji validitas (X1) semua item pertanyaan (X1) yang berupa pemahaman peraturan perundangan ketenagakerjaan adalah valid dengan probabilitas value sebesar 0,000 yang signifikan pada taraf $1 \%$. Uji validitas (X2) berupa kesejahteraan adalah valid dengan probabilitas value sebesar 0,000 yang signifikan pada taraf $1 \%$. Uji validitas (X3) berupa serikat pekerja adalah valid dengan probabilitas value sebesar 0,000 yang signifikan pada taraf $1 \%$. Pada uji validitas (Y) berupa harmonisasi pekerja dan pengusaha adalah valid dengan probabilitas value sebesar 0,000 yang signifikan pada taraf $1 \%$. Nilai Alpha Cronbach adalah 0,61 dan dikatakan reliabel (lebih besar dari nilai 0,60) setelah item nomor 4 untuk $\mathrm{X} 2$ dihapus.

Reliabilitas untuk variabel (X1), pada X2 nilai Cronbach Alpha sebesar 0,488 lebih kecil dari 0,60 dan dkatakan tidak reliabel, pada X3 Cronbach Alpha diperoleh 0,90 yang lebih besar dari 0.60, reliabel, dan untuk Y Cronbach Alpha sebesar 0,73 yang mana lebih besar dari pada 0,60, maka variabel Y reliabel.

Nilai tolerance untuk X1 sebesar 0,962, X2 sebesar 0,868 dan X3 sebesar 0,884 yang mana nilai tersebut lebih besar dari 0,10 , maka dalam hal ini dinyatakan lolos uji multikolinieritas. Uji Autokorelasi sebesar 0,315 yang artinya keadaan yang tidak signifikan, maka dinyatakan lolos.Uji Heteroskedastisitas, Probabilitas value untuk tiap variabel bebas $(\mathrm{X} 1=$ 0,129; X2 = 0,097 dan X3 = 0,215) tidak signifikan dinyatakan lolos. Uji Normalitas sebesar 0,5 artinya menunjukkan keadaan yang tidak signifikan, bearti lolos. Koefisien determinasi 0,16 (16\%) dan $84 \%$ dipengaruhi oleh variabel lain yang tidak diteliti.
Berdasarkan hasil uji di atas, dapat ditarik kesimpulan model yang digunakan lolos uji jadi dapat dibuat sebuah interprestasi terhadap model tersebut. Berikut uji signifikansi individual.

\section{Tabel 1. Nilai t hitung pada SPSS (12)}

\begin{tabular}{llll}
\hline $\mathrm{X} 1$ & $=$ & Signifikan & $\begin{array}{l}\text { Probabilitas } \\
\text { value } 0,021\end{array}$ \\
\hline $\mathrm{X} 2,350$ & & Signifikan & $\begin{array}{l}\text { Probabilitas } \\
\text { value } 0,001\end{array}$ \\
3,580 & & & Probabilitas \\
$\mathrm{X} 3$ & $=$ & Tidak & value 0,052 \\
1,970 & & Signifikan & \\
\hline
\end{tabular}

Pada hasil X1 dan X2 adalah signifikan, maka nilai koefisien dan tandanya memiliki arti. Apabila X1 meningkat, maka $\mathrm{Y}$ akan meningkat, demikian pula sebaliknya.

Kemudian apabila X2 meningkat, maka $\mathrm{Y}$ juga akan meningkat, demikian pula sebaliknya.

Dengan mengacu pada landasan hukum maupun teorinya, maka hasil uji di atas adalah telah sesuai dengan ketentuan yang ada. Persamaan regresi linier berganda $Y=4,883+0,166 X_{1}+0,451 X_{2}+0,243 X_{3}$.

Interpretasi dari hasil tersebut, nilai 4,883 artinya bahwa harmonisasi antara pekerja dengan pengusaha akan meningkat bersamaan dengan pemahaman peraturan perundangan ketenagakerjaan, kesejahteraan, dan serikat pekerja yang meningkat juga. 0,166 berarti variabel $Y$ akan meningkat sebesar 0,166, asumsi X2 dan X3 dianggap tetap. 0,451 artinya variabel $\mathrm{Y}$ akan meningkat sebesar 0,451 , asumsi variabel X1 dan X3 dianggap tetap. 0,243 bearti variabel $\mathrm{Y}$ meningkat sebesar 0,243, asumsi X1 dan $\mathrm{X} 2$ dianggap tetap. Nilai $\mathrm{F}$ hitung adalah 7,209 dan probabilitas value 0,000 yang signifikan pada taraf $\alpha=$ $5 \%$. Maka Ho yang menyatakan bahwa semua variabel (X1, X2 dan X3) tidak mempunyai pengaruh bersama-sama terhadap variabel dependen dapat ditolak.

\section{KESIMPULAN}

Dari uraian yang telah diinformasikan sebelumnya dapat diambil kesimpulan bahwa variabel X1, X2, dan X3 mempunyai pengaruh yang positif dan signifikan terhadap Y, namun demikian variable X3 tidak signifikan terhadap Y. Dapat dikatakan bahwa semua variabel bebas secara simultan dapat menjelaskan variabel dependennya (Y). Agar tercipta hermonisasi di perusahaan, maka pekerja dan pengusaha harus mentaati serta melaksanakan ketentuan peraturan perundangan yang berlaku, dan perlunya peningkatan peran dan fungsi lembaga pembinaan dan pengawasan bidang ketenagakerjaan. 


\section{DAFTAR PUSTAKA}

Robbins, Stephen P. 1996, Perilaku Organisasi, PT. Indeks Kelompok Gramedia, Jakarta

Bimo Walgito, 1990, Psikologi Sosial, Andi Offset, Yogyakarta

Sondang P. Siagian, 2002, Manajemen Sumber Daya Manusia, Bumi Aksara, Jakarta

Payaman J. Simanjuntak, 2003, Manajemen Hubungan Industrial, Pustaka Sinar Harapan, Jakarta

Yogiyanto H.M., 2004, Metodologi Penelitian Bisnis, BPFE, Yogyakarta

Fred N Kerlinger dan Elazar J. Pedhazur (Nur Cahaya, 1987), Korelasi dan Analisis Regresi Ganda

Triton PB, 2005, Paradigma Baru Manajemen Sumber Daya Manusia, Tugu, Yogyakarta

Sonny Sumarsono, 2003, Ekonomi Manajemen Sumber Daya Manusia dan Ketenagakerjaan, Graha Ilmu, Yogyakarta

Suwarto, 2005, Hubungan Industrial dalam Praktik, Asosiasi Hubungan Industrial, Indonesia, Jakarta

Wahana Komputer, 2005, Pengembangan Analisis Multivariate dengan SPSS 12, Penerbit Salemba Infotek, Jakarta

UU No. 21 Tahun 2000 Tentang Serikat

Pekerja/Serikat Buruh

UU No. 3 Tahun 1992 Tentang Jamsostek

UU No. 13 Tahun 2003 Tentang

Ketenagakerjaan

UU No. 2 Tahun 2004 Tentang

Penyelesaian Perselisihan Hubungan Industrial. 
482 Coopetition, Vol 12, Nomor XII, November 2021,

(E-ISSN : 2615-4978, P-ISSN : 2086-4620) 